\title{
Correlation between clinical signs of feline conjunctivitis and molecular detection of felid herpesvirus-1, feline calicivirus, chlamydophila felis and mycoplasma felis in cats from shelters in Rio de Janeiro
}

\section{Correlação entre sinais clínicos da conjuntivite felina e a detecção molecular de felid herpesvirus-1, feline calicivirus, chlamydophila felis e mycoplasma felis em gatos de abrigos no Rio de Janeiro}

\author{
Natasha BAUMWORCEL ${ }^{1}$; Ana Maria Barros SOARES²; Sheila Bruna SILVA; \\ Núbia Karla Oliveira ALMEIDA ${ }^{4}$; Tatiana Xavier de CASTRO ${ }^{1}$ \\ ${ }^{1}$ Universidade Federal Fluminense, Instituto Biomédico, Departamento de Microbiologia e Parasitologia, Niterói - RJ, Brazil
${ }^{2}$ Universidade Federal Fluminense, Faculdade de Veterinária, Niterói - RJ, Brazil
${ }^{3}$ Instituto Biomédico Universidade Federal Fluminense, Departamento de Microbiologia e Parasitologia, Niterói - RJ, Brazil
${ }^{4}$ Universidade Federal Fluminense, Instituto de Matemática e Estatística, Departamento de Estatística, Niterói - RJ, Brazil
}

Abstract

Objectives: To perform molecular diagnosis of microbial agents (FHV-1, FCV, Mycoplasma felis, and Chlamydophila felis) in kittens with conjunctivitis and correlate the clinical signs with clinical severity. Material and Methods: A total of 108 conjunctival swab were collected from kittens without $(\mathrm{G} 1 ; \mathrm{n}=40)$ and with $(\mathrm{G} 2 ; \mathrm{n}=68)$ clinical signs of conjunctivitis. Animals from G2 group were scored from 1 (mild) to 4 (severe) according to the severity of conjunctivitis. All samples were submitted to PCR and RT-PCR. Results: FHV-1 was detected in 62/108 (57.4\%) of samples, FCV in 40/108 (37.0\%), M. felis in 11/108 (10.2\%) and C. felis in 26/108 (24.1\%). Mixed infections were detected in 39/108 (36.1\%). In G1, 28/40 (70.0\%) were positive for one or more agents, in $\mathrm{G} 2,58 / 68$ (85.3\%) were positive ( $\mathrm{P}=0.03)$. In 1 , single infections by FHV-1were found in 21/40 (52.5\%) samples, FCV in 2/40 (5.0\%), C. felis in 1/40 (2.5\%), and no pathogens were detected in 12/40 (30\%) of samples, while mixed infections accounted for 29/40 (72.5\%) of the cases. In G2, single FHV-1 infections were found in 31/68 (45.6\%) samples, FCV in 10/68 (14.7 \%), M. felis in 2/68 (3.0\%) and C. felis also in $2 / 68(3.0 \%)$, and no pathogens were detected in 10/68 (14.7\%) samples, while mixed infections accounted for 36/68 (52.0\%) of the cases. They were categorized as grade 1, 20/68 (29.4\%), grade 2, 14/68 (20.6\%), grade 3, 21/68 (30.9\%) and grade 4, 13/68 (19.1\%). The presence of FHV-1 and FCV is equally distributed among the four categories. More severe clinical signs, scores 3 and 4, are related to coinfections by C. felis and M. felis. Conclusions: FHV-1, FCV, C. felis and M. felis were identified in feline conjunctivitis. Co-infections are related to more severe cases of conjunctivitis. Molecular diagnosis is helpful to detect asymptomatic carriers and is a rapid and accurate method to determine the pathogen of feline conjunctivitis.

Keywords: Ocular infection. Felis catus. Polymerase chain reaction. Upper respiratory tract disease. Eye.

\section{Resumo}

O objetivo deste estudo foi realizar diagnóstico molecular de agentes microbiológicos (FHV-1, FCV, Mycoplasma felis e Chlamydophila felis) em gatos filhotes e associar a presença dos patógenos à gravidade dos sinais clínicos de conjuntivite. Foram coletadas um total de 108 amostras de suabe conjuntival de filhotes felinos assintomáticos $(\mathrm{G} 1 ; \mathrm{n}=40)$ e sintomáticos (G2; $\mathrm{n}=68$ ). Animais do G2 foram categorizados de 1 (leve) até 4 (grave), de acordo com o quadro clínico de conjuntivite. As 108 amostras foram submetidas à PCR e RT-PCR. O FHV-1 foi detectado em 57,4\% das amostras, o FCV em $37 \%$, o $M$. felis em $10,2 \%$ e o C. felis em $24,1 \%$. Coinfecções, por sua vez, foram detectadas em $36,1 \%$. No G1, $70 \%$ das amostras foram positivas para um ou mais patógenos. No G2, 85,3\% apresentavam infecções $(\mathrm{P}=0,03)$. No G1, monoinfecções por FHV-1 foram diagnosticadas em 52,5\% das amostras, por FCV em 5\%, por C. felis em 2,5\%, e em 30\% das amostras analisadas nenhum dos patógenos estudados foi encontrado. Coinfecções, por sua vez, estavam presentes em 72,5\% das amostras. No G2, monoinfecções por FHV-1 foram encontradas em 45,6\% das amostras, por FCV em 14,7 \%, por M. felis em 3\% e por C. felis também em 3\%. Nenhum dos patógenos estudados foi encontrado em $14,7 \%$ das amostras analisadas. Coinfecções, responsáveis por 52\% dos casos, foram categorizados como Grau $1(29,4 \%)$, Grau 2 (20,6\%), Grau 3 (30,9\%) e Grau 4 (19,1\%). A presença de FHV-1 e FCV está igualmente distribuída entre as quatro categorias. Os sinais clínicos mais graves (graus 3 e 4) estão relacionados a coinfecções por C. felis e M. felis. Os 
agentes microbiológicos FHV-1, FCV, C. felis e M. felis foram encontrados em animais com conjuntivite. Coinfecções estão relacionadas aos casos mais graves. Por fim, concluiu-se que o diagnóstico molecular, além de detectar portadores assintomáticos, é um método rápido e acurado para o diagnóstico do patógeno causador da conjuntivite felina.

Palavras-chave: Infecção ocular. Felis catus. Reação em cadeia pela polimerase. Doença do trato respiratório superior. Olho.

\section{Correspondence to:}

Natasha Baumworcel

Universidade Federal, Instituto Biomédico, Departamento de

Microbiologia e Parasitologia

Rua Professor Hernani Melo, 101

CEP 24210-130, Niterói, RJ, Brazil

E-mail: natashaveterinaria@gmail.com

Received: 23/09/2015

Approved: 11/01/2017

\section{Introduction}

Feline conjunctivitis is a worldwide disease among cats, no matter if they are housed or sheltered animals. The clinical presentation can be both acute and chronic (COYNE et al., 2006; GOURKOW et al., 2013; POLAK et al., 2014) viral and bacterial agents have been identified alone or in co-infected animals. The more common pathogens are Felid Herpesvirus 1 (FHV-1), Feline calicivirus (FCV) (BANNASCH; FOLEY, 2005; GASKELL et al., 2007), Mycoplasma felis (LOW et al., 2007) and Chlamydophila felis (HARTLEY, 2010; BRADLEY et al., 2012). Different clinical signs of conjunctivitis may be seen depending on age at infection, immune status and whether the infection is primary or recrudescent. Acute or primary ocular infection is characterized by conjunctival hyperemia, serous ocular discharge, chemosis and blepharospasm. Reactivation of herpesvirus may cause recrudescent disease (MAGGS; CLARKE, 2005).

All pathogens mentioned above have also been identified in cases of feline conjunctivitis (SYKES et al., 2001; HARTMANN et al., 2010; HALÁNOVÁ et al., 2011), but their correlation with the severity of clinical signs remains to be elucidated. Particularly, Felid herpesvirus 1 (FHV-1) and Feline calicivirus (FCV) (BERGER et al., 2015), are responsible for the majority of the conjunctivitis cases (HARTLEY, 2010). Feline chlamydiosis (Chlamydophila felis) can be considered the main cause of bacterial conjunctivitis in kittens (HOLST et al., 2010; PŁONECZKA-JANECZKO et al., 2011).

Diagnosis of infectious conjunctivitis is mostly presumptive, mainly due to the overlap in clinical signs and the presence of infections in nonclinical animals (MCMANUS et al., 2014).

The use of molecular techniques such as polymerase chain reaction (PCR) and reverse transcription polymerase chain reaction (RT-PCR) allows early and conclusive diagnosis of infectious conjunctivitis, providing that appropriate therapy could be instituted (LOW et al., 2007; RUCH-GALLIE et al., 2011; SÁNCHEZ et al., 2012; BARRADO et al., 2014; FERNANDEZ et al., 2016). The management of infected cats within a multi-cat household situation requires appropriate separation of cats and routine hygiene practices for facilities and personnel also viral shedding may occur without clinical signs of conjunctivitis (MAGGS et al., 1999; MAGGS; CLARKE, 2005). So the earlier detection by PCR technics could possible adequate segregation of contagious animals.

The aim of this study was to perform the molecular diagnosis of FHV-1, FCV, C. felis and M. felis in cats with signs conjunctivitis compared with a control population of asymptomatic cats in order to study their correlation of genome detection with the severity of the clinical signs. The main hypotheses were that more severe cases of conjunctivitis would be related to a specific pathogen alone or related to co-infected animals and that circulation of main conjunctivitis pathogens from multi-cat households in Rio de Janeiro, Brazil, are similar from reported in other countries.

\section{Material and Methods}

\section{Ethical statement}

This study was licensed by the Ethics Committee of Animal Research of Universidade Federal Fluminense CEUA No 330/2013.

\section{Animals}

A total of 88 unvaccinated kittens (male and female) aged from two months to one year were studied between September 2013 and June 2014 from public and private shelters in Rio de Janeiro. The animals were housed 
together and only untreated kittens were included in the study. From each animal, a complete ophthalmological examination was conducted by the same veterinarian and signs of conjunctivitis were scored on a scale according to Hartmann et al. (2010) the prevalence of feline herpesvirus (FHV: Group 1 (score 0) included animals without conjunctivitis. Group 2 included animals with conjunctivitis divided in four scores: 1 (mild conjunctival hyperaemia); 2 (moderate conjunctival hyperaemia and mild chemosis); 3 (moderate to severe conjunctival hyperaemia and moderate chemosis); 4 (severe conjunctival hyperaemia and severe chemosis).

Considering those examinations, 40 samples were assigned group 1 (one sample was collected from the right eye of each cat). A total of 68 samples were assigned group 2: 28 of them had unilateral and the remaining 40 bilateral conjunctivitis. Samples were taken by rolling a DNA/RNAse free cytobrush (Cytobrush PlusR, Trumbull ${ }^{\circ}$ ) (BAUER et al., 1996) in the ventral conjunctival fornix (HILLSTRÖM et al., 2012).

\section{Genome extraction, reverse transcription (RT) and polymerase chain reaction (PCR) to detect FCV, FHV-1, M. felis and C. felis}

DNA and RNA extractions were performed immediately after collection using a PureLink Spin Column-Based Kit - Genomic DNA (Invitrogen ${ }^{\varpi}$ ). Reverse Transcription was performed using random primers (Invitrogen ${ }^{\circledR}$ ) and the Superscript III enzyme (Invitrogen ${ }^{\circ}$ ) according to the manufacturer's instructions. PCR followed by a nested PCR for FCV detection was performed with CDNA isolated from each sample using two sets of primers (Cali1/Cali2 and Cali3/Cali4) targeting, respectively, 924-bp and 467-bp regions of the gene encoding the conserved capsid region (ORF2 or region B) of FCV (MARSILIO et al., 2004; COYNE et al., 2006) and Platinum Taq DNA Polymerase III (Invitrogen ${ }^{\oplus}$ ).

For FHV-1 detection, a 287-bp region of the thymidine kinase gene was amplified by PCR using the HerpF (5' - GACGTGGTGAATTATCAGC - 3' - position 510) / HerpR (5'- CAACTAGATTTCCACCAGGA - 3' position 797) primer pair as described by Henzel et al. (2012). Ten $\mu \mathrm{L}$ of DNA extracted were mixed with $40 \mu \mathrm{L}$ of the mixture of the reagents and primers Herp F/ Herp R. Cycling used: one cycle for denaturation of 5 minutes at $94^{\circ} \mathrm{C}$, followed by 40 cycles of 45 seconds at $94^{\circ} \mathrm{C}, 30$ seconds $56^{\circ} \mathrm{C}, 45$ seconds at $72^{\circ} \mathrm{C}$, and 7 final minutes at $72^{\circ} \mathrm{C}$.
For FCV, a cDNA synthesis was performed from RNA extracted using a random primer 48190-011 (Invitrogen ${ }^{\circ}$ Life Technologies, U.S.A.). The cDNA synthesis was performed from RNA extracted using the random primer 48190-according to the manufacturer's instructions. To obtain cDNA, $10 \mu \mathrm{L}$ of ssRNA was added to $40 \mu \mathrm{L}$ of the RT reaction mixture, for a total final volume of $50 \mathrm{~mL}$. The mixture was placed in a thermocycler (Swift Escohealthcare $\mathrm{MaxPro}^{\circ}$ ) at $25^{\circ} \mathrm{C}$ for 5 minutes, followed by $50^{\circ} \mathrm{C}$ for 60 minutes and $70^{\circ} \mathrm{C}$ for 20 minutes. The c-DNA obtained was stored at $-20^{\circ} \mathrm{C}$.

From the cDNA previously obtained, Nested PCR was carried out with primers Cali1 (AACCTGCGCTAACGTGCTTA 5'-3 'position 5322-5341) and Cali2 (CAGTGACAATACACCCAGAAG 5'-3' position 6225-6246), which amplified a fragment of 924-bp of the gene encoding the conserved capsid region (ORF2 or region B) (COYNE et al., 2006).

The second amplification reaction was then carried out with primers internal Cali3 (TGGTGATGATGAATGGGCATC 5'-3 'position 5514-5535) and Cali4 (ACACCAGAGCCAGAGATAGA 5'-3' position 5971-5991) generating a 467-bp fragment as described by Marsilio et al. (2004). The cycling used: one cycle for denaturation of 5 minutes at $94^{\circ} \mathrm{C}$, followed by 35 cycles of 1 minute at $94^{\circ} \mathrm{C}, 45$ seconds at $57^{\circ} \mathrm{C}, 1$ minute at $72^{\circ} \mathrm{C}$, and $7 \mathrm{final}$ minutes at $72^{\circ} \mathrm{C}$. Same cycle was used for RT-PCR and Nested-PCR

For M. felis detection, a 187-bp region of the 16S/23S intergenic rRNA was amplified with the Myc1 (CACCGCCCGTCACACCA 5'-3')/ Myc2 (AGGCATCCACCAAAAACTCT 5'-3') primer pair as described by Chalker et al. (2004). Five $\mu \mathrm{L}$ of DNA extracted were mixed with $20 \mu \mathrm{L}$ of the mixture of the reagents and primers $\mathrm{Mycl} / \mathrm{Myc} 2$. The cycling used: one cycle for denaturation of 5 minutes at $94^{\circ} \mathrm{C}$, followed by 30 cycles of 1 minute at $94^{\circ} \mathrm{C}, 40$ seconds at $54^{\circ} \mathrm{C}, 1$ minute at $72^{\circ} \mathrm{C}$, and 5 final minutes at $72^{\circ} \mathrm{C}$.

For C. felis detection, a 1094-bp region of the 16S gene was amplified with the ChlaF (ATGAAAAAACTCTTGAAATCGG 5'-3' position 364) / ChlaR (CAAGATTTTCTAGACTTCATTTTGTT 5'-3' position 1458) primer pair as described by Sykes et al. (2001). $5 \mu \mathrm{L}$ of DNA extracted were mixed with $20 \mu \mathrm{L}$ of the mixture of the reagents and primers ChlaF/ChlaR. The cycling used: one cycle for denaturation of 5 minutes at $94^{\circ} \mathrm{C}$, followed by 30 cycles of 1 minute at $94^{\circ} \mathrm{C}, 40$ seconds at $54^{\circ} \mathrm{C}, 1$ minute at $72^{\circ} \mathrm{C}$, and 5 final minutes at $72^{\circ} \mathrm{C}$. 
For the PCR reactions detecting FHV-1, FCV, and C. felis, a commercially available vaccine, Felocell CVR-C vaccine ${ }^{\oplus}$ (Pfizer Animal Health), was used as a positive control. For the M. felis PCR, a positive clinical sample (RJ051/13) was used as positive control. All the positive controls were purified using a QIAquick PCR Purification Kit (Qiagen ${ }^{\circledR}$ ) and were sequenced in both directions using a Big Dye Terminator Kit ${ }^{\circledast}$ (Applied Biosystems). The specificity of the fragment was confirmed using a BLAST search. Positive controls were submitted to genbank ( $M$. felis: KY249129; C. felis KY 249130; FHV-1 KP 888923.1; FCV KY283109). Milli-Q water was also subjected to the DNA extraction process and used as a negative control.

All amplified products were analyzed on $1.5 \%$ agarose gel electrophoresis at $100 \mathrm{~V}$ for 50 minutes, using a 100-bp DNA ladder (Invitrogen Life Technologies, U.S.A). The products were photographed in U Ex-Pix Documentation system (LOCCUS Biotechnology ${ }^{\oplus}$ ).

\section{Statistical analysis}

A database of the ophthalmologic and clinical examinations was assembled and stored in an Excel spreadsheet, Windows 2013. The statistical significance for $(\alpha=0.05)$ the association between variables was determined by chi-square $\left(\chi^{2}\right)$ and Fisher's exact test using $R$, version 3.1.1 (2010).

\section{Results}

Overall, FHV-1 was detected in 62 (57.4\%) samples, FCV in 40 (37\%), C. felis in 26 (24\%), M. felis 11 (10.2\%).

Considering animals from $\mathrm{Gl}$ (control cats), the presence of only one of the studied microorganisms represented $24 / 40(60.0 \%)$ samples, while the presence of more than one microorganism was observed in $4 / 40$ (10.0\%). In 12/40 (30.0\%) no pathogen was detected. Out of the animals with the presence of only one microorganism, 21/40 (52.5\%) tested positive for FHV-1, two (5.0\%) for FCV and one (2.5\%) for C. felis, while the ones with more than one microorganism detected were represented by the combinations FHV-1+ FCV (three samples) and one with FHV-1 + C. felis.

In relation to $\mathrm{G} 2$, single infections were detected in $23 / 68$ samples $(33.8 \%)$, while mixed infections were observed in 35/68 (51.4\%). In 10/68 (14.70\%) no agent was detected. Of the single infections, 10/68 (14.7\%) tested positive for FHV-1, 10/68 (14.7\%) for FCV, 2/68 (3.0\%) for C. felis and 1/68 (1.5\%) for M. felis. Considering mixed infections, several combinations were observed, which are detailed in table 1.

Table 1 - Distribution of the microorganisms detected in 108 conjunctival swab samples from kittens housed in public or private shelters in Rio de Janeiro - Brazil - 2014

\begin{tabular}{lcccc}
\hline & Assymptomatic & Symptomatic & Total (n) & $\%$ \\
\hline C. felis & 1 & 1 & 2 & 1,9 \\
FCV & 2 & 10 & 12 & 11,1 \\
FHV-1 & 21 & 10 & 31 & 28,7 \\
M. felis & 0 & 2 & 2 & 1,9 \\
FCV + C. felis & 0 & 5 & 5 & 4,6 \\
FCV + C. felis + M. felis & 0 & 1 & 1 & 0,9 \\
FCV + FHV-1 & 3 & 8 & 11 & 10,2 \\
FCV + FHV-1 + C. felis & 0 & 7 & 7 & 6,5 \\
FCV + FHV-1 + C. felis + M. felis & 0 & 2 & 2 & 1,9 \\
FCV + M. felis & 0 & 2 & 2 & 1,9 \\
FHV-1 + C. felis & 1 & 6 & 7 & 6,5 \\
FHV-1 + C.felis + M. felis & 0 & 2 & 2 & 1,9 \\
FHV-1+ M. felis & 0 & 2 & 2 & 1,9 \\
Negative & 12 & 10 & 22 & 20,4 \\
Total & 40 & 68 & 108 & 100 \\
\hline
\end{tabular}

FHV-1, felid herpesvirus; FCV, feline calicivirus; C. felis, Chlamydophila felis; M. felis, Mycoplasma felis 
The severity of the conjunctivitis was scored according to clinical signs. Score 1 (mild signs) was reported in 20 eyes (29.4\%), while score 2 (moderate signs) in $14(20.6 \%)$, score 3 (severe signs) in 21 $(30.9 \%)$, and score 4 (very severe signs) in 13 eyes (19.1\%) (Table 2).

Table 2 - Distribution of the microorganisms detected in 68 samples of G2 (symptomatic animals), according to scores, Rio de Janeiro - Brazil - 2014

\begin{tabular}{|c|c|c|c|c|c|c|c|c|c|}
\hline & score 1 & p-value & score 2 & p-value & score 3 & p-value & score 4 & p-value & Total \\
\hline FHV-1 & 4 & * & 3 & * & 2 & * & 1 & * & 10 \\
\hline FCV & 5 & $*$ & 2 & * & 2 & * & 1 & * & 10 \\
\hline C. felis & 0 & * & 0 & * & 1 & * & 0 & * & 1 \\
\hline M.felis & 1 & * & 0 & * & 1 & * & 0 & * & 2 \\
\hline FHV-1 + FCV & 2 & * & 3 & * & 1 & * & 2 & * & 8 \\
\hline FHV-1 + C. felis & 1 & * & 1 & * & 3 & * & 1 & * & 6 \\
\hline FHV-1 + M. felis & 0 & $P<0.05$ & 0 & * & 2 & * & 0 & * & 2 \\
\hline FCV + C. felis & 1 & * & 1 & * & 1 & * & 2 & * & 5 \\
\hline FCV + M. felis & 0 & * & 1 & * & 0 & * & 1 & * & 2 \\
\hline C. felis + M. felis & 0 & * & 0 & * & 0 & $*$ & 0 & * & 0 \\
\hline FHV-1 + FCV + C. felis & 0 & $P<0.05$ & 2 & * & 2 & * & 3 & * & 7 \\
\hline FHV-1 + FCV + M. felis & 0 & * & 0 & * & 0 & * & 0 & * & 0 \\
\hline FHV-1 + C. felis + M. felis & 0 & * & 0 & * & 2 & $\mathrm{P}<0.05$ & 0 & * & 2 \\
\hline FCV + C. felis + M. felis & 0 & * & 0 & * & 1 & * & 0 & * & 1 \\
\hline FHV-1 + FCV + C. felis + M. felis & 0 & $P<0.05$ & 0 & * & 2 & $P<0.05$ & 0 & * & 2 \\
\hline Negative & 6 & * & 1 & * & 1 & * & 2 & * & 10 \\
\hline Total & 20 & & 14 & & 21 & & 13 & & 68 \\
\hline
\end{tabular}

FHV-1, felid herpesvirus 1; FCV, feline calicivirus; C. felis, Chlamydophila felis; M. felis, Mycoplasma felis. Score 1 - mild signs; score 2 - moderate signs; score 3- severe sigs; score 4-very severe signs

${ }^{\star}$ Not statistically significant

Mono-infections were mainly caused by virus (FHV1 and FCV) and were equally distributed among the different scores. Virus infections, either single or associated (FHV-1+FCV) were significantly correlated to score 1 $(\mathrm{P}=0.008)$. Bacteria were mostly associated with viruses in ocular surface infections. Co-infection of only two bacteria and mono-infection by $C$. felis or $M$. felis were not statistically relevant. When clinical signs were correlated to microbiological results, it could be noticed that higher scores ( 3 and 4 ) were significantly related to co-infections $(P=0.003)$. Bacteria were related to score $3(P=0.03)$ and score $4(\mathrm{P}=0.008)$. Infections by $M$. felis were not found to be associated with any kind of virus.

\section{Discussion}

To our knowledge, this is the first study performed in Brazil associating the molecular detection of these four pathogens (FHV-1, FCV, M. felis, and C. felis) with the clinical severity of cats with conjunctivitis using, at the same time, PCR and RT-PCR.

Overall, the high prevalence of viral agents was not unexpected, and can be understood by their efficient mechanisms to escape from the immune system (MOCHIZUKI et al., 2000; SZPARA et al., 2014). What was really unexpected was the high occurrence of FHV1 on asymptomatic kittens; it was the most common pathogen on animals of G1, and was detected on barely half of them. Although FHV-1 is recognized as the most common cause of feline ocular disease (MAGGS; CLARKE, 2005; HARTLEY, 2010), its occurrence in asymptomatic kittens is not often reported. Consideration must be given to the fact that FHV-1 is shed intermittently and remains latent in the trigeminal ganglia most of the time, undetectable by PCR (BINNS et al., 2000). So, once it was detected it is possible that its presence on low viral load in those kittens explains the absence of clinical signs, 
but that assumption requires further quantitative studies in order to be confirmed.

It is noteworthy that asymptomatic cats can represent an important source of infection (BATTILANI et al., 2013; MÖSTL et al., 2013), so constant surveillance including molecular testing for FHV-1 may be important for the sanity of those animals. The animals in the present study were housed together regardless of whether they were showing clinical signs or not. Living in a multi-cat household was, in fact, an important risk factor, as previously described (HELPS et al., 2005; BERGER et al., 2015). In the only shelter where cats were separated according to symptoms, there were no rules and sanitary barriers regarding the people who worked with these animals. In this way, staff might be responsible for carrying pathogens from one side to the other. All animals (control group and symptomatic cats) were the same age, unvaccinated and not tested for other viral pathogens such as FIV or FeLV.

In relation to FCV, it has traditionally been considered as a minor primary conjunctival pathogen (MOCHIZUKI et al., 2000; GERRIETS et al., 2012; BERGER et al., 2015). In the present study it was observed in the same proportion as FHV-1, both in G1 and G2, in different scores, and it is possible that its role has been neglected. This observation underlines the importance of asymptomatic shedders in FCV epidemiology, as previously described by Berger et al. (2015). FCV present high genetic variability (COYNE et al., 2006), which can be responsible for the observed diversity on the severity of clinical signs.

C. felis was previously associated with the severity of ocular signs (FERNANDEZ et al., 2016). In the present study C. felis DNA was detected in association with other pathogens in $53.8 \%$ of the samples scored 4 . In contrast, it was found alone in only two animals, one asymptomatic and the other with severe signs (score 4), including conjunctival hyperemia and severe chemosis. Similar findings were observed for $M$. felis; although not detected as a cause of mono-infection, it was present in eleven cases of co-infections. Therefore, it is possible to infer that, although not apparently capable of determining clinical conjunctivitis alone, these bacteria may play an important role complicating pre-existing infections as has been suggested by other authors (SYKES et al., 2001; HARTMANN et al., 2010). Our data suggest that, for clinical diagnosis of conjunctivitis by FHV-1, FCV, C.felis, and M.felis infections, symptoms overlap and therefore diagnosis has to be confirmed by molecular testing
A high genetic variability is expected for FCV (ABDELDAIM et al., 2009; BERGER et al., 2015) and the specificity of the PCR primers may have been a limitation of the study.

The present study identified a high occurrence of different pathogens (viral and bacterial) in clinical and asymptomatic kittens. Particularly the occurrence of virus both in mono- or co-infections helps clarify the role of those agents in ocular surface infections. Co-infections were very common in the present study as reported in previous studies (BERGER et al., 2015; FERNANDEZ et al., 2016).

Although very useful, molecular diagnosis of conjunctivitis is not routinely employed on veterinary ophthalmology. In the last decade those tests became affordable and their regular usage could help the diagnosis of viral infections, consequently preventing the unnecessary use of antibiotics. Worldwide many cats (including asymptomatic) remain latently infected with FHV-1 and represent a source of infection (STILES; POGRANICHNIY, 2008; HARTLEY, 2010). Rapid and accurate identification of the infected cats by PCR would also assist in control programs.

\section{Conclusion}

Pathogens mentioned in this paper identified by PCR and RT-PCR in cases of feline conjunctivitis in Rio de Janeiro, Brazil, were similar from those reported in other countries. Except for M. felis, the others were also detected in asymptomatic animals. Viruses were the most commonly detected infectious agents in kittens with and without clinical signs of conjunctivitis. Co-infections are related to more severe cases of conjunctivitis.

\section{Acknowledgments}

We thank Walter Lilenbaum, Bruno de A. Penna, Ceci Ribeiro, and Daniel Lessa for critically reading the manuscript.

\section{Funding Section}

The current study was supported by Fundação Carlos Chagas Filho de Amparo à Pesquisa do Estado do Rio de Janeiro (FAPERJ) grant number E-26/110.600/2014. Baumworcel, N. was the master's student recipient of a scholarship from Coordenação de Aperfeiçoamento de Pessoal de Nível Superior (CAPES) for participating in the Graduate Program of Microbiologia e Parasitologia Aplicadas, Universidade Federal Fluminense. 


\section{References}

ABD-ELDAIM, M. M.; WILKES, R. P.; THOMAS, K. V.; KENNEDY, M. A. Development and validation of a TaqMan real-time reverse transcription-PCR for rapid detection of feline calicivirus. Archives of Virology, v. 154, n. 4, p. 555-560, 2009. doi: 10.1007/s00705-009-0337-5.

BANNASCH, M. J.; FOLEY, J. E. Epidemiologic evaluation of multiple respiratory pathogens in cats in animal shelters. Journal of Feline Medicine and Surgery, v. 7, n. 2, p. 109 119, 2005. doi: 10.1016/j.jfms.2004.07.004.

BARRADO, L.; SUAREZ, M. J.; PÉREZ-BLÁZQUEZ, E.; OTERO, J. R.; FOLGUEIRA, M. D. Could polymerase chain reaction tests on conjunctival swabs be useful to diagnose herpetic keratitis? Enfermedades Infecciosas y Microbiología Clínica, v. 32, n. 1, p. 28-30, 2014. doi: 10.1016/j.eimc.2013.07.005.

BATTILANI, M.; VACCARI, F.; CARELLE, M. S.; MORANDI, F.; BENAZZI, C.; KIPAR, A.; SCAGLIARINI, A. Virulent feline calicivirus disease in a shelter in Italy: a case description. Research in Veterinary Science, v. 95, n. 1, p. 283-290, 2013. doi: 10.1016/j.rvsc.2013.01.025.

BAUER, G. A.; SPIESS, B. M.; LUTZ, H. Exfoliative cytology of conjunctiva and cornea in domestic animals: a comparison of four collecting techniques. Veterinary and Comparative Ophthalmology, v. 6, n. 3, p. 181-186, 1996.

BERGER, A.; WILLI, B.; MELI, M. L.; BORETTI, F. S.; HARTNACK, S.; DREYFUS, A.; LUTZ, H.; HOFMANNLEHMANN, R. Feline calicivirus and other respiratory pathogens in cats with Feline calicivirus-related symptons and in clinically healthy cats in Switzerland. BMC Veterinary Research, v. 11, p. 282-293, 2015. doi: 10.1186/s12917-015-0595-2.

BINNS, S. H.; DAWSON, S.; SPEAKMAN, A. J.; CUEVAS, L. E.; HART, C. A.; GASKELL, C. J.; MORGAN, K. L.; GASKELL, R. M. A study of feline upper respiratory tract disease with reference to prevalence and risk factors for infection with feline calicivirus and feline herpesvirus. Journal of Feline Medicine and Surgery, v. 2, n. 3, p. 123-133, 2000. doi: 10.1053/jfms.2000.0084.
BRADLEY, A.; KINYON, J.; FRANA, T.; BOLTE, D.; HYATT, D. R.; LAPPIN, M. R. Efficacy of intranasal administration of a modified live feline herpesvirus 1 and feline calicivirus vaccine against disease caused by Bordetella bronchiseptica after experimental challenge. Journal of Veterinary Internal Medicine, v. 26, n. 5, p. 1121-1125, 2012. doi: 10.1111/j.1939-1676.2012.00982.x.

CHALKER, V. J.; OWEN, W. M. A.; PATERSON, C. J. I.; BROWNLIE, J. Development of a polymerase chain reaction for the detection of Mycoplasma felis in domestic cats. Veterinary Microbiology, v. 100, n. 1-2, p. 77-82, 2004. doi: 10.1016/j.vetmic.2004.01.014.

COYNE, K. P.; REED, F. C.; PORTER, C. J.; DAWSON, S.; GASKELL, R. M.; RADFORD, A. D. Recombination of Feline calicivirus within an endemically infected cat colony. Journal of General Virology, v. 87, n. 4, p. 921-926, 2006. doi: 10.1099/vir.0.81537-0.

FERNANDEZ, M.; MANZANILLA, E. G.; LLORET, A.; LEÓN, M.; THIBAULT, J. C. Prevalence of feline herpesvirus-1, feline calicivirus, Chlamydophila felis and Mycoplasma felis DNA and associated risk factors in cats in Spain with upper respiratory tract disease, conjunctivitis and/or gingivostomatitis. Journal of Feline Medicine and Surgery, p. 1-9, 2016. In press. doi: $10.1177 / 1098612 X 16634387$.

GASKELL, R.; DAWSON, S.; RADFORD, A.; THIRY, E. Feline herpesvirus. Veterinary Research, v. 38, n. 2, p. 337-354, 2007. doi: 10.1051/vetres:2006063.

GERRIETS, W.; JOY, N.; HUEBNER-GUTHARDT, J.; EULE, J. C. Feline calicivirus: a neglected cause of feline ocular surface infections? Veterinary Ophthalmology, v. 15, n. 3, p. 172-179, 2012. doi: 10.1111/j.1463-5224.2011.00957.x.

GOURKOW, N.; LAWSON, J. H.; HAMON, S. C.; PHILLIPS, C. J. C. Descriptive epidemiology of upper respiratory disease and associated risk factors in cats in an animal shelter in coastal western Canada. Canadian Veterinary Journal, v. 54, n. 2, p. 132-138, 2013. 
HALÁNOVÁ, M.; SULINOVÁ, Z.; CISLÁKOVÁ, L.; TRBOLOVÁ, A.; PÁLENÍK, L.; WEISSOVÁ, T.; HALÁN, M.; KALINOVÁ, Z.; HOLIČKOVÁ, M. Chlamydophila felis in cats: are the stray cats dangerous source of infection? Zoonoses and Public Health, v. 58, n. 7, p. 519-522, 2011. doi: 10.1111/j.1863-2378.2011.01397.x.

HARTLEY, C. Aetiology of corneal ulcers assume FHV1 unless proven otherwise. Journal of Feline Medicine and Surgery, v. 12, n. 1, p. 24-35, 2010. doi: 10.1016/j. jfms.2009.12.004.

HARTMANN, A. D.; HAWLEY, J.; WERCKENTHIN, C.; LAPPIN, M. R.; HARTMANN, K. Detection of bacterial and viral organisms from the conjunctiva of cats with conjunctivitis and upper respiratory tract disease. Journal of Feline Medicine and Surgery, v. 12, n. 10, p. 775-782, 2010. doi: 10.1016/j.jfms.2010.06.001.

HELPSC.R.; LAIT,P.;DAMHUIS, A.;BJÖRNEHAMMAR, U.; BOLTA, D.; BROVIDA, C.; CHABANNE, L.; EGBERINK, H.; FERRAND, G.; FONTBONNE, A.; PENNISI, M. G., GRUFFYDD-JONES, T.; GUNNMOORE, D.; HARTMANN, K.; LUTZ, H.; MALANDAIN, E.; MÖSTL, K.; STENGEL, C.; HARBOUR, D. A.; GRAAT, E. A. M. Factors associated with upper respiratory tract disease caused by feline herpesvirus, feline calicivirus, Chlamydophila felis and Bordetella bronchiseptica in cats: experience from 218 European catteries. Veterinary Record, v. 156, n. 21, p. 669-673, 2005. doi: 10.1136/ vr.156.21.669.

HENZEL, A.; BRUM, M. C. S.; LAUTERT, C.; MARTINS, M.; LOVATO, L. T.; WEIBLEN, R. Isolation and identification of feline calicivirus and feline herpesvirus in Southern Brazil. Brazilian Journal of Microbiology, v. 43, n. 2, p. 560-568, 2012. doi: 10.1590/ S1517-83822012000200017.

HILlSTRÖM, A.; TVEDTEN, H.; KÄLlBERG, M.; HANÅS, S.; LINDHE, A.; HOLST, B. S. Evaluation of cytologic findings in feline conjunctivitis. Veterinary Clinical Pathology, v. 41, n. 2, p. 283-290, 2012. doi: 10.1111/j.1939-165X.2012.00423.x.

HOLST, B. S.; HANÅS, S.; BERNDTSSON, L. T.; HANSSON, I.; SÖDERLUND, R.; ASPÁN, A.; SJÖDAHL-
ESSÉN, T.; BÖLSKE, G.; GREKO, C. Infectious causes for feline upper respiratory tract disease: a case-control study. Journal of Feline Medicine and Surgery, v. 12, n. 10, p. 783-789, 2010. doi: 10.1016/j.jfms.2010.06.002.

LOW, H. C.; POWELL, C. C.; VEIR, J. K.; HAWLEY, J. R.; LAPPIN, M. R. Prevalence of feline herpesvirus 1, Chlamydophila felis, and Mycoplasma spp DNA in conjunctival cells collected from cats with and without conjunctivitis. American Journal of Veterinary Research, v. 68 , n. 6, p. 643-648, 2007. doi: 10.2460/ajvr.68.6.643.

MAGGS, D. J.; CLARKE, H. E. Relative sensitivity of polymerase chain reaction assays used for detection of feline herpesvirus type 1 DNA in clinical samples and commercial vaccines. American Journal of Veterinary Research, v. 66, n. 9, p. 1550-1555, 2005. doi: 10.2460/ ajvr.2005.66.1550.

MAGGS, D. J.; LAPPIN, M. R.; REIF, J. S.; COLLINS, J. K.; CARMAN, J.; DAWSON, D. A.; BRUNS, C. Evaluation of serologic and viral detection methods for diagnosing feline herpesvirus-1 infection in cats with acute respiratory tract or chronic ocular disease. Journal of the American Veterinary Medical Association, v. 214, n. 4, p. 502-507, 1999.

MARSILIO, F.; DI MARTINO, B.; AGUZZI, I.; MERIDIANI, I. Duplex polymerase chain reaction assay to screen for feline herpesvirus-1 and Chlamydophila spp. in mucosal swabs from cats. Veterinary Research Communications, v. 28, p. 295-298, 2004. Supplement 1. doi: 10.1023/B:VERC.0000045430.15950.fa.

MCMANUS, C. M.; LEVY, J. K.; ANDERSEN, L. A.; MCGORRAY, S. P.; LEUTENEGGER, C. M.; GRAY, L. K.; HILLIGAS, J.; TUCKER, S. J. Prevalence of upper respiratory pathogens in four management models for unowned cats in the Southeast United States. The Veterinary Journal, v. 201, n. 2, p. 196-201, 2014. doi: 10.1016/j.tvjl.2014.05.015.

MOCHIZUKI, M.; KAWAKAMI, K.; HASHIMOTO, M.; ISHIDA, T. Recent epidemiological status of feline upper respiratory infections in Japan. Journal of Veterinary Medical Science, v. 62, n. 7, p. 801-803, 2000. doi: 10.1292/ jvms.62.801. 
MÖSTL, K.; EGBERINK, H.; ADDIE, D.; FRYMUS, T.; BOUCRAUT-BARALON, C.; TRUYEN, U.; HARTMANN, K.; LUTZ, H.; GRUFFYDD-JONES, T.; RADFORD, A. D.; LLORET, A.; PENNISI, M. G.; HOSIE, M. J.; MARSILIO, F.; THIRY, E.; BELÁK, S.; HORZINEK, M. C. Prevention of infectious diseases in cat shelters: ABCD guidelines. Journal of Feline Medicine and Surgery, v. 15, n. 7, p. 546-554, 2013. doi: 10.1177/1098612X13489210.

PŁONECZKA-JANECZKO, K.; KIEŁBOWICZ, Z.; BANIA, J.; BEDNAREK, K. Real-time PCR detection of Mycoplasma felis in domestic cats suffering from chronic conjunctivitis (Poland). Polish Journal of Veterinary Sciences, v. 14, n. 4, p. 679-681, 2011. doi: 10.2478/v10181-011-0103-y.

POLAK, K. C.; LEVY, J. K.; CRAWFORD, P. C.; LEUTENEGGER, C. M.; MORIELLO, K. A. Infectious diseases in large-scale cat hoarding investigations. The Veterinary Journal, v. 201, n. 2, p. 189-195, 2014. doi: 10.1016/j.tvjl.2014.05.020.

RUCH-GALLIE, R. A.; VEIR, J. K.; HAWLEY, J. R.; LAPPIN, M. R. Results of molecular diagnostic assays targeting feline herpesvirus- 1 and feline calicivirus in adult cats administered modified live vaccines. Journal of Feline Medicine and Surgery, v. 13, n. 8, p. 541-545, 2011. doi: 10.1016/j.jfms.2010.12.010.

SÁNCHEZ, M. D.; GOLDSCHMIDT, M. H.; MAULDIN, E. A. Herpesvirus dermatitis in two cats without facial lesions. Veterinary Dermatology, v. 23, n. 2, p. 171-173, 2012. doi: 10.1111/j.1365-3164.2011.01031.x.

STILES, J.; POGRANICHNIY, R. Detection of virulent feline herpesvirus-1 in the corneas of clinically normal cats. Journal of Feline Medicine and Surgery, v. 10, n. 2, p. 154-159, 2008. doi: 10.1016/j.jfms.2007.10.006.

SYKES, J. E.; ALLEN, J. L.; STUDDERT, V. P.; BROWNING, G. F. Detection of feline calicivirus, feline herpesvirus 1 and Chlamydia psittaci mucosal swabs by multiplex RT-PCR/PCR. Veterinary Microbiology, v. 81, n. 2, p. 95-108, 20w01. doi: 10.1016/ S0378-1135(01)00340-6.

SZPARA, M. L.; GATHERER, D.; OCHOA, A.; GREENBAUM, B.; DOLAN, A.; BOWDEN, R. J.; ENQUIST, L. W.; LEGENDRE, M.; DAVISON, A. J. Evolution and diversity in human herpes simplex virus genomes. Journal of Virology, v. 88, n. 2, p. 1209-1227, 2014. doi: 10.1128/JVI.01987-13. 